\title{
Strategizing for Innovation: An Empirical Investigation on Strategic Orientation and Innovation Types
}

\author{
Tahseen Arshi \& Gargi Chugh \\ Majan College (University College), Muscat, Oman \\ E-mail: tahseen.arshi@majancollege.edu.om
}

Received: March 2, 2013

Accepted: March 26, 2013

Published: April 23, 2013

doi: 10.5296/ bmh.v1i1.3573

URL: http://dx.doi.org/10.5296/ bmh.v1i1.3573

\begin{abstract}
Innovation is a key competence that most firms wish to acquire as it has been established that innovation can provide the necessary competitive advantage. However, firms struggle to develop appropriate strategic direction that may provide the necessary competitive advantage through innovation. Strategizing for innovation becomes even more challenging as innovation comes in different forms and sizes. This study attempts to unravel the complexities associated with innovation and strategizing. The findings provide clear directions to firms as the critical dimensions of strategy are prescribed for both radical and incremental innovation.
\end{abstract}

\section{Value/ originality}

Theoretical insights from both strategy and innovation literature informs this study to develop empirical guidelines for strategy design. This is one of the first studies that associate different strategic orientations for both radical and incremental innovation. This study fills a critical gap in the literature as earlier studies have focused on strategy and innovation in a very generic context.

\section{Rationale}

The role strategy in promoting innovation in organizations has found considerable amount of acceptance in the literature. However, the richness of extant literature on strategic orientation gets limited when strategy is studied in the context of innovation, especially innovation scale and frequency. Clear strategic directions are not available to firms based on their innovation focus. It is therefore quite observable that many of the innovation efforts fail and unable to provide these firms with requisite competitive advantage. The limited clarity on the concept of innovation itself makes it difficult to analyze strategy within a prescribed and valid framework. Since this study focuses on strategic orientation within the context of radical and 


\section{Macrothink}

Business and Management Horizons

ISSN 2326-0297 2013, Vol. 1, No. 1

incremental innovation, academic and practitioners will have a better understanding of strategic decision making for each type of innovation. Specific strategies can be designed depending on the innovation type and objectives.

Keywords: strategy, competitive advantage, radical innovation, incremental innovation 


\section{Introduction}

Strategy is both critical and at the same time paradoxical. Critical because in an age where differentiation is the key, a clear strategic direction to achieve a sustainable competitive advantage based on innovation is always elusive and paradoxical because, while strategy traditionally meant planning for the long-term, the fast pace of innovation, particularly disruptive innovation, does not really allow the firm to fix long-term goals. According to a report by Boston Consulting Group (2010) successful large firms regard innovation as a top strategic priority and they believe that it is innovation that enabled them to emerge out of recession. Ahmed and Shepherd (2010) pointed out that the strategy should be two-pronged. First, that strategies should envision the innovation process and outputs that the firm wishes to deliver and second, that the strategic aim should be to align its capabilities and competencies such that it can produce, implement and sustain innovative processes and outputs. Stalk et al. (1992) had earlier argued that it is important that the key competencies are transformed into strategic competencies to provide superior value. Burgelman (1991) also contended that the key competence is the ability of the firm to 'renew' itself so that the competencies are sustainable. Liedtke and Rosenblum (1996) also supported this view by saying that the key is on developing and shaping new competencies and designing strategies in line with such objectives as innovation. The literature on strategy and innovation needs to be appropriately exploited (explored) so that strategic orientations that lead to innovation can be clearly identified. This study is an effort in that direction. The extant literature on strategy and innovation was reviewed to identify key strategic impetuses that lead to innovation. The strategic orientation towards both radical and incremental innovation were identified and tested.

\subsection{Global Hypothesis}

Strategic orientation has a significant impact on innovation capability of the firms

HO: Specific aspects on strategy design impact innovation scale and frequency (represented as incremental and radical innovation)

\section{Literature Review}

The landscape of strategic thought and discussion has been dominated by Porters' (1980) strategy model. One of his most prominent strategies from this model that has been relevant for innovation management has been the strategy of 'differentiation', which is based on the risk-tolerance capabilities for the firm. Ahmed and Shepherd (2010) argued that the cost reduction strategies can also be innovative and should be considered as an important strategic and innovative capability. They argued that organizational learning, which is a typical example of process innovation that leads to significant cost efficiencies which can also give a sustainable competitive advantage.

Once product innovations set the tone and other variants make their place in the market, and the dominant design settles in. Every firm's strategy at this moment is to be as close as possible to this dominant design. While process innovation, strives to build efficiency in the customers value and delivery process, strategic direction from this point in time should focus 
on innovation, distributing the equilibrium, and aim for renewal, and radical transformation of the innovation. Firms that are proactive in strategic innovation are effective entrepreneurial organizations and Atuehene-Gima and Ko (2001) contended that it is these proactive firms that have the capability to alter the competition and adopt strategies that are based on market intelligence, customer’s feedback and responsiveness.

\subsection{Strategy and Innovation}

Hyland and Beckett (2005) contended that strategies that focused on innovation should be adequately evaluated because ideally these innovation focused strategies should be able to enhance the strategic capability of the firm. These researchers argued that the all the strategies of a firm need not be innovative all the time because strategic focus on innovation is an investment for the future. They further pointed out that all the ideas may not succeed in the long run and there may be strategic tensions across the innovation landscape. These views are also supported by De-Wit and Meyer (2004). Although innovation strategies draw substantially from the strategy literature, it has a few inherent paradoxes that seem to be incompatible. De-Wit and Meyer (2004) highlights some of the strategic tensions and paradoxes as shown in table 1 .

Table 1. Strategic tensions while developing innovation strategies source: De-Wit and Meyer (2004)

\begin{tabular}{|ll|}
\hline Strategic Tension & Elaboration \\
\hline Logic versus creativity & $\begin{array}{l}\text { Strategy is about logic. Creativity and innovation } \\
\text { is all about thinking and experimentation }\end{array}$ \\
\hline $\begin{array}{l}\text { Planned versus emergent } \\
\text { Environmental strategy is designed based on emerging } \\
\text { environmental shaping (constraint versus } \\
\text { choice) }\end{array}$ & $\begin{array}{l}\text { long-terms strategies? Quinn and Voyer (1998) } \\
\text { had initially suggested incrementalism to deal } \\
\text { environmental conditions or organizational } \\
\text { objectives. Environmental conditions itself can } \\
\text { be changed or managed. Clark (2004) pointed } \\
\text { out that disruptive innovations change the } \\
\text { environmental conditions. }\end{array}$ \\
\hline Environment led versus resource led & $\begin{array}{l}\text { Strategic choices are determined either by } \\
\text { environmental opportunities or organization's } \\
\text { resources and competencies. The value of } \\
\text { resources and competencies are discussed in } \\
\text { detail by Prahalad and Hamel (1990) through } \\
\text { resourced based view (RBV) approach and Teece } \\
\text { (2007) as dynamic capabilities. }\end{array}$ \\
\hline
\end{tabular}


Notwithstanding the strategic tensions, researchers such as De Geus (2002) and Hickman and Raia (2002) called for a more balanced approach between innovation, stability and efficiency. The last point in table 1 brings out the importance of resources and competencies in strategic decision-making. The strategies should not only ensure that unique, rare and inimitable competencies are developed by the entrepreneurial organization but also permeates throughout the organization. The importance of intellectual capital (Nonka and Takeuchi 1995) and social capital (Subramaniam and Youndt 2005) has been highlighted in the management of innovation. These views are based on organizations' individual capabilities. However there is a growing body of literature on the importance of networks and value chain that are of central importance for the strategic management of innovation in organizations. Lavie (2006) viewed these as 'relational assets', a key output of networking capabilities. George (2005) stated the importance of slack resources in firms that provide more capabilities during tough times and facilitates experimentation and risk taking. George (2005) also found a positive relationship between slack resources and economic performance of the firm.

In terms of strategic choices, entrepreneurial firms have strategic options available from the three main innovation strategies. These include:

- $\quad$ First to the market

- $\quad$ Second to the market

- 'Late' to the market

Strategic leverage gained from the first mover advantage is well known. These strategies allow the firms to develop products and services that customers do not expect or even require at that point in time. Although market related strategies are risky, it makes entrepreneurial firms highly innovative (Hult and ketchen 2001). These firms are pioneers within the industry and the pioneers' costs are always lower than the followers' costs in the long run. These lower costs are achieved because of a higher market share and a faster learning curve. However, when these innovations are protected across the value chain, Ahmed and Shepherd (2010) pointed out that in such scenarios competitors are 'locked out' and customers are 'locked in'. Once customers are locked in through customized offerings, customers' switching costs become higher. Competitors on the other hand are locked out through a continuous stream of innovations and patents, protecting knowledge sources and enhancing capabilities and managerial commitment. However, the risks associated with such an innovation strategy are related to market and technological uncertainty (Boulding and Christen 2001). Porter (1985) and Liebermann (2006) argued that late entry strategies to the market, on the other hand, allow firms to hedge against such risk and uncertainty, because late entry strategies allow these risks to disappear once pioneers bring innovative products or services to the market.

Ahmed and Shepherd (2010) elaborated that entrepreneurial organizations are caught up between the two extreme strategies. On one side is the attraction to capitalize on the opportunity cost, while on the other side is the danger of risks involved. Firms that choose to 
capitalize on the opportunity cost make speedy entry into the market but in industries where risks are high, late entry strategies are preferred. Decomposition therefore would be an ideal strategy for firms which believe that opportunity costs and risks are equally important. By following an incremental innovation strategy they tend to keep both, their costs and risks under control.

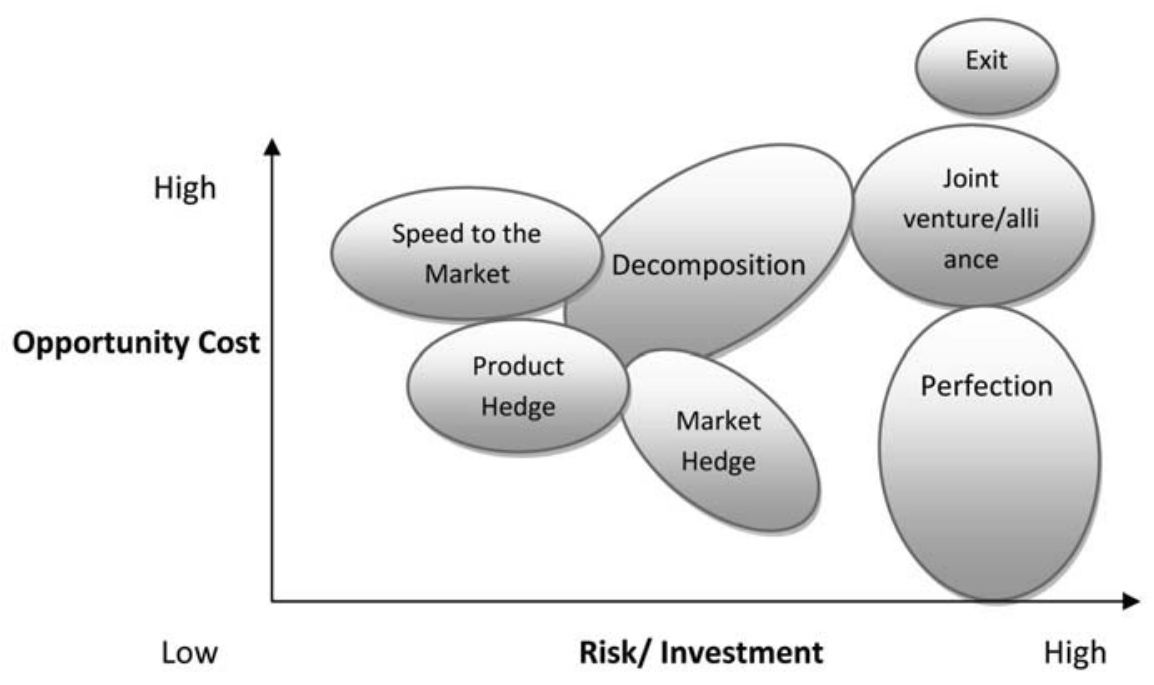

Figure 1. Options map for innovative strategies, source: Ahmed and Shepherd (2010)

While an incremental innovation strategy manages to control both opportunity cost and risks, the real challenge is for firms that follow disruptive innovation strategies. According to Christen and Raynor (2003) and Gilbert (2003) disruptive innovation strategies have the following characteristics:

- Disruptive innovations underperforms on the mainstream customer value

- Mainstream customers do not value drastically different innovative changes

- Disruptive innovations appeal to lower end price-sensitive customers as it reduces the overall cost and hence limits the potential profit enhancement

- Mainstream customers only adopt the innovation when further developments take place and they can see value in it

Firms adopting disruptive innovation strategies should realize that the value of the strategy would only be realized with time. Secondly, an important strategic insight is that disruptive innovation strategies displace dominant incumbents even though they were always listening to their mainstream customer's and deciding their strategies based on customer insights (Tellis 2006). Firms that follow disruptive innovation strategies always force the other players in the industry to change the rules. 
While competition has been a critical factor in strategic thinking, it has gained center stage in the last few years and that is as Kim and Mauborgne (2005) pointed out because, in the present knowledge economy competitive dynamics have changed significantly. Firstly, there is more potential for increasing returns and secondly, knowledge as resource is not mutually exclusive and allows free-riding. According to Kim and Mauborgne (2005) the strategic focus should therefore shift on creating 'value innovation'. Value innovation is focused on enhancing buyers' benefits or value creation. They argued that innovation without value creation can be too radical or wild or it may be too 'technology oriented' and 'futuristic' and might fail to capture customers' imagination or readiness. The researchers quoted various examples from industries which indicated that technology innovations without value creation have not proved to be successful. Kim and Mauborgne (1998b) had pointed out that the strategic focus of innovation should move away from competition to customers. Staying focused on competition limits firms to incremental innovation as firms are focused on imitative strategic moves and reactive behavior. Companies who want to develop effective strategies for innovation should concentrate on their resources and capabilities that create superior value for the customers.

Amabile (1998) recommended smaller autonomous units and diverse teams (Kanter 1996) that can make such value innovation happen. Alder (2006) supported these recommendations as he argued that clear structure and reporting relationships and procedures are essential for innovation. Dougherty (2006) proposed that innovation should be integrated across all structures across the organization so that organizations can learn. These views were in sharp contrast to those of Tushman and O'Reilly (1997) who had recommended separation of organizational routine work from innovation led activities.

Blue ocean strategy is one of most critical strategies that have been associated with value innovation. Value innovation is the cornerstone of this strategy which aligns cost, price and utility positions (Kim and Mauborgne 2005). The worth of Blue ocean strategy lies in its ability to combine both the strategies of low cost and differentiation. Blue ocean strategy called for creating uncontested market space by creating new market boundaries and reaching beyond existing demand. This reconstructed strategic thinking, which ignores traditional competitive barriers, creates unlimited opportunities like the expanse of Blue Ocean. For implementing this strategy successfully, it is essential that leaders and the organizations eliminate key hurdles like cognitive, resource, motivational and political that could hamper the process of breaking free from the status quo, dedicating resources and shifting the strategic thinking (Kim and Mauborgne 2005).

\subsection{Incremental and Radical Innovation}

Bessant and Tidd (2011) argued that innovation varies on the degree of their novelty and innovations may range from minor improvements- termed as incremental innovation to radical changes- termed as radical innovation. They further argued that the former is usually characterized by changes in components and as changes in systems-an explanation that is found in some of innovation models. Both radical and incremental innovation has different competitive consequences and requires different organizational capabilities. Tidd and Bessant 
(2009) have enumerated the benefits of both types of innovation in delivering competitive advantage. Kanter (2010) argued that organizations must have capabilities for incremental innovation before they can acquire new capabilities for radical innovation. On the other hand, Christensen and Overdorf (2005) cautioned that organizations with incremental innovation capabilities often fail to handle revolutionary changes and hence their ability to meet the challenges of disruptive innovation becomes restricted. Prahlad and Mashelkar (2010) pointed out that radical innovations are disruptive and changes the industry dynamics thus providing substantial level of competitive advantage.

The literature, on strategy and innovation neither provides any conclusive evidence on how different strategic orientations lead to either incremental of radical innovation, and nor are any standard scales found in the literature to measure the relationship. Therefore, to operationalize the constructs a sound methodological base was required.

\section{Methodology}

Although a construct like strategy qualifies to be epistemologically grounded in interpretivist philosophy on the merit that this abstract construct demands subjective explanation, this research could not ignore its limitations in terms of measurement. Therefore a realist perspective with influences of positivism was adopted to facilitate measurement and enhance validity (Fisher 2004). Positing the research into realist philosophy meant that quantitative strategies became dominant and hence a cross- sectional research design was adopted. Quantitative methods provided a framework for the study and statistical persuasion became critical to validity. Quantitative strategies allowed measurement with greater control and as recommended by Saunders (2012) allowed greater amount of reliability and generalisability.

\subsection{Operationalization of Constructs}

The dimensions of strategy were treated as independent variables, while radical and incremental innovations were considered as dependent variables. The primary research tool that was adopted was a questionnaire survey using a five point Likert scale. A 40-item questionnaire was constructed and 20 items of strategy dimensions were allocated to both types of innovation through two sets of questionnaires. The dimensions were also validated through qualitative interviewing. Using a sampling strategy of a combination of judgment and simple random sampling data was collected from 200 employees working in different private sector organizations in Oman. The sectors that were included in this study were telecommunications, banking, retail, tourism, airlines, and financial services.

\subsection{Reliability and Validity}

A total of 40 items (all scale data) were subjected to the alpha test to ensure reliability. The reliability test of the interval scaled data showed a high internal consistency as the Cronbach Alpha value was 0.762 which is by all means highly desirable as suggested by Saunders et al. (2006). Homoscedasticity was checked using Tabachnik and Fidell's (2007) and Pallant's (2005) recommendations. The Leven's test (.613 and .711) and multi-collinearity and variation inflationary factor (VIF) also showed desirable scores. (Tolerance less than 10 and VIF greater than 2.5 was achieved) There was no auto-correlation detected in the data as was 
indicated through the Durbin Watson Test (1.899 and 1.881). These tests indicated that there were no violations of the assumptions of regression equations. Validity was very important as the items in the questionnaire were being tested for the first time and no other standard scales were available. Face validity and content validity was established through extensive survey of the extant literature on both innovation and strategy. The factors were regressed to establish convergent validity and verimax rotation scores showed high convergent validity. It meant that each of the 20 items (strategic dimensions) was qualified to measure both types of innovation constructs. The data was analyzed using multiple regressions as the normal distribution of the data warranted parametric tests (Pallant 2005).

\section{Findings and Data Presentation}

The 40 items used in the questionnaire were subjected to the Pearson Product moment correlation test. Out of the40 items that were subjected to testing, 21 items showed strong correlation values $(\mathrm{P}>.05)$ as shown in table 2 below.

Table 2. Pearson Product moment correlation test (DV incremental and radical innovation)

\begin{tabular}{|c|c|c|}
\hline Strategy & Innovation Type & \\
\hline Dimensions & Radical innovation & Incremental Innovation \\
\hline $\begin{array}{l}\text { Focusing on fringes of } \\
\text { mainstream market }\end{array}$ & .760 & \\
\hline Dismantle core capabilities & $.728 * *$ & \\
\hline Defy dominant design & $.742 * *$ & \\
\hline Competency enhancing & & $.670^{* *}$ \\
\hline Working around punctured equilibrium & & $.498 * *$ \\
\hline Blue ocean strategy & $.809 * *$ & \\
\hline Competency enhancing & & $.498^{* *}$ \\
\hline Creation of new business models & $.616 * *$ & \\
\hline Continuous improvement & & $.750 * *$ \\
\hline Organizational climate supporting creativity & & $.899 * *$ \\
\hline Extending the mandate of innovation & $.512 *$ & \\
\hline Bottom up strategy & & $.740 * *$ \\
\hline Top Down Strategy & $.812 * *$ & \\
\hline Enhance productivity & & $.510^{*}$ \\
\hline Benchmarking & & $.623 *$ \\
\hline Programmed deviations & $.520^{*}$ & \\
\hline Exploitation of current strategies and business model & & .491 \\
\hline Focus on quality enhancement & & $.697 * *$ \\
\hline Transformation strategy & $.682 * *$ & \\
\hline Level of inter-firm collaboration & $.689^{* *}$ & \\
\hline Ability to reconfigure value chain & $.745^{* *}$ & \\
\hline
\end{tabular}




\section{Macrothink}

Business and Management Horizons

ISSN 2326-0297

2013, Vol. 1, No. 1

The findings indicated that the respondents could identify strategies that lead to either incremental or radical innovation. Table 2 shows that 11 dimensions of strategy contribute towards radical innovation outputs, while 10 dimensions contribute towards incremental innovation outputs. Further, to evaluate the collective impact of all dimensions on these types of innovation multiple regression tests were conducted and the results are presented in tables 3 and 4.

Table 3. Regression on dimensions for strategy and radical innovation construct (DV) P>.05

\section{Model Summary: Radical Innovation Strategy}

\begin{tabular}{|l|l|l|l|l|l|}
\hline $\begin{array}{l}\text { Mode } \\
\mathrm{l}\end{array}$ & $\mathrm{R}$ & $\begin{array}{l}\mathrm{R} \\
\text { Square }\end{array}$ & $\begin{array}{l}\text { Adjusted } \\
\text { R Square }\end{array}$ & $\begin{array}{l}\text { Std. Error of } \\
\text { the Estimate }\end{array}$ & Durbin-Watson \\
\hline 1 & $.812(\mathrm{a})$ & .644 & .601 & .68677 & $\mathbf{1 . 8 9 9}$ \\
\hline
\end{tabular}

Test of Homogeneity of Variances

\begin{tabular}{|l|l|l|l|}
\hline Levene Statistic & df1 & df2 & Sig. \\
\hline .613 & 4 & 195 & .692 \\
\hline
\end{tabular}

\begin{tabular}{|c|c|c|c|c|c|c|}
\hline \multirow{2}{*}{\multicolumn{2}{|c|}{ Model }} & \multicolumn{2}{|c|}{$\begin{array}{l}\text { Un-standardized } \\
\text { Coefficients }\end{array}$} & \multirow{2}{*}{\begin{tabular}{|l}
$\begin{array}{l}\text { Standardized } \\
\text { Coefficients }\end{array}$ \\
Beta \\
\end{tabular}} & \multirow[t]{2}{*}{$\mathbf{t}$} & \multirow[t]{2}{*}{ Sig. } \\
\hline & & \multirow{2}{*}{$\begin{array}{l}\mathrm{B} \\
.408 \\
\end{array}$} & \multirow{2}{*}{$\begin{array}{l}\text { Std. } \\
\text { Error } \\
.266\end{array}$} & & & \\
\hline 1 & (Constant) & & & & 1.538 & .126 \\
\hline & $\begin{array}{l}\text { Focusing on fringes of } \\
\text { mainstream market }\end{array}$ & .406 & .086 & .399 & 4.729 & .000 \\
\hline & Dismantle core capabilities & .123 & .075 & .119 & 1.645 & .002 \\
\hline & Defy dominant design & .015 & .072 & .013 & .211 & .013 \\
\hline & Top Down Strategy & .512 & .069 & .411 & 1.785 & .000 \\
\hline & Transformation strategy & .577 & .048 & .379 & 1.987 & .001 \\
\hline
\end{tabular}

Table 4. Regression on dimensions for strategy and incremental innovation construct (DV) $\mathrm{P}>.05$

\section{Model Summary: Incremental Innovation Strategy}

\begin{tabular}{|l|l|l|l|l|l|}
\hline $\begin{array}{l}\text { Mode } \\
\mathrm{l}\end{array}$ & $\mathrm{R}$ & $\begin{array}{l}\mathrm{R} \\
\text { Square }\end{array}$ & $\begin{array}{l}\text { Adjusted } \\
\text { R Square }\end{array}$ & $\begin{array}{l}\text { Std. Error of } \\
\text { the Estimate }\end{array}$ & Durbin-Watson \\
\hline 1 & .840 & .712 & .699 & .61213 & $\mathbf{1 . 8 8 1}$ \\
\hline
\end{tabular}


Test of Homogeneity of Variances

\begin{tabular}{|l|l|l|l|}
\hline Levene Statistic & df1 & df2 & Sig. \\
\hline .711 & 4 & 195 & .719 \\
\hline
\end{tabular}

\begin{tabular}{|c|c|c|c|c|c|c|}
\hline \multirow{2}{*}{\multicolumn{2}{|c|}{ Model }} & \multicolumn{2}{|c|}{$\begin{array}{l}\text { Un-standardized } \\
\text { Coefficients }\end{array}$} & \multirow{2}{*}{$\begin{array}{l}\text { Standardized } \\
\text { Coefficients }\end{array}$} & \multirow[t]{2}{*}{$\mathbf{t}$} & \multirow[t]{2}{*}{ Sig. } \\
\hline & & \multirow{2}{*}{$\begin{array}{l}\mathrm{B} \\
.408 \\
\end{array}$} & \multirow{2}{*}{$\begin{array}{l}\text { Std. } \\
\text { Error } \\
.266\end{array}$} & & & \\
\hline \multirow[t]{8}{*}{1} & (Constant) & & & & 1.538 & .107 \\
\hline & Competency enhancing & .406 & .086 & .374 & 4.729 & .001 \\
\hline & $\begin{array}{l}\text { Working around punctured } \\
\text { equilibrium }\end{array}$ & .123 & .075 & .119 & 1.645 & .102 \\
\hline & Continuous improvement & .213 & .072 & .398 & 1.711 & 000 \\
\hline & $\begin{array}{l}\text { Focus on quality } \\
\text { enhancement }\end{array}$ & .169 & .075 & .159 & 2.263 & .025 \\
\hline & Enhance productivity & .370 & .072 & .380 & 1.229 & .001 \\
\hline & Bottom up Strategy & .343 & .087 & .039 & 1.645 & .003 \\
\hline & $\begin{array}{l}\text { Organizational climate } \\
\text { supporting creativity }\end{array}$ & .123 & .056 & .119 & 2.200 & .029 \\
\hline
\end{tabular}

The findings indicate that there is a strong and positive relationship between dimensions of strategy and the innovation construct. Further, dimensions of strategy and innovation types were also found to be correlated. Dimensions of strategy and incremental and radical innovation showed significant correlation values. Most prominent relationships that are reported between radical innovations and strategy include, working on fringes of mainstream markets (.000), dismantling of core capabilities (.002), defying dominant logic (.013), following top down strategy (.000) and focusing on transformation strategy (.001)

The presentation of the multiple regression models (table 3) explains almost 70\% (adjusted $\mathrm{R}$ square) of the relationship between dependent (incremental innovation) and independent variables (dimensions of strategy) in this model. Top down strategy with the highest beta score of .411 (p value .000) contributes maximum towards radical innovation outputs followed by working on fringes of mainstream markets with a beta score of .399 leading to opportunities for radical innovation. The presentation of the multiple regression models (table 4) explains almost $70 \%$ (adjusted $R$ square) of the relationship between dependent (incremental innovation) and independent variables (dimensions of strategy) in this model. Continuous improvement strategy with a beta score of .398 (p value .000) contributes maximum towards incremental innovation outputs followed by focus on enhancing competencies with a beta score of .374 leading to opportunities for incremental innovation. 


\section{Discussion}

The findings and the literature both, have confirmed that strategy can significantly determine innovation capabilities which were also confirmed by (Hyland and Beckett 2005). It also established the fact that the different strategic orientations lead to different levels of innovation outputs. On one hand, innovation that is radical has a deep impact on the market and the key players establish new competitive rules and challenge the dominant design. While on the other hand, incremental innovation is instrumental in enhancing the organizations' capacity to enhance productivity and competencies, stay close to its customers, strive for continuous improvement and promote a climate for creativity and innovation.

Strategies for incremental innovation operate within the framework of existing strategies, culture, and structure of the firm, while the strategies for radical innovation out rightly reject the established conventions of strategy making. Existing competencies do not require to be upgraded but abandoning, existing markets and mainstream customers have to be ignored and dominant design has to be challenged. It implies that, to follow strategies to enhance radical innovation capabilities takes lot of courage and conviction. Working on the fringes of mainstream markets according to Kim and Mauborgne (2005) is the cornerstone of blue ocean strategy. Similarly underplaying to the mainstream customers according to Christen and Raynor (2003) and Gilbert (2003) provides opportunities for firms to think radically different and design products and services that make competition irrelevant. It is thus not a cliché that firms with radical innovation capacities are rare but a reality. The primary reason is that such courage and conviction that defies conventional logic is the luxury of few in a competitive landscape where most incumbents focus their strategies on operational excellence and incremental improvements. Top down strategy therefore is more closely associated with radical innovation and strategy making. Bessant and Tidd (2011) argued that firms make innovation happen but it is not possible without an almost intoxicating mixture of vision, passion, energy, enthusiasm and judgment. The role of leadership in providing such commitment and courage has to be investigated in greater detail and provides scope for further research.

Strategies for incremental innovation, on the other hand, fit the logical thinking framework better. Operations concepts such as continuous improvement and quality management therefore dominate strategic thinking in this context. These improvements are geared to enhance productivity and quality. Listening to various stakeholders particularly customers is critical to a continuous improvement strategy. Tellis (2006) linked bottom up strategy to incremental innovation as customer's feedback is encouraged and the information permeates back into the organization through front lines and reaches the top for strategic directions. Strategic orientations for incremental innovation therefore focus on resources and capabilities that create superior value for the customers. Since structure, strategies and processes are stable and efficient, entire portfolios of incremental substantive decisions are delegated to the middle management where direct expertise and information resides. Strategy, cultural values and mission are emphasized by the leaders during evolutionary periods. The strategies for incremental innovation call for continuous improvements, exploitation of existing capabilities and designing strategies for customer inputs into innovation. If these strategies do not have 
provision for feedback from multiple stakeholders improvement efforts may not cater to the needs of the customers. Incremental strategies are largely driven by market pull and bottoms-up approach rather than top down approach evidenced in radical innovation strategies.

\section{Conclusions}

It can be explained therefore that incremental innovation can be viewed as doing something better, while radical innovation can be viewed as doing something different. While the former involves strategies to exploit and explore, the later involves re-framing and re-designing of strategies. It is therefore not a coincidence that radical innovations are harder to find. Neither this study, nor the literature concludes that one is better than the other. The strategic orientation for each is different and firms should develop strategies based on the conditions they are facing. The strategic choices may be influenced by market and competitive conditions, industry and product life cycles and larger demographic and economic factors. This study has been able to establish that firms should not be lost when choosing their strategies for innovation. There should be clear strategic direction when firms have to choose between the innovation types and the basis for competitive advantage. Each set of factors identified in this study leads to different types of innovation and must be clearly differentiated as firms strategize for innovation.

\section{References}

Ahmed, P. K., \& Shepherd, C. D. (2010). Innovation Management, Context, Strategies, Systems and Process. UK: Person Education.

Alder, P. (2006). Routinization of Innovation. Working Paper, University of Southern California.

Amabile, T. M. (1988). A model of creativity and innovation in organizations. Research in Organizational Behavior, 19, 123-67.

Atuahene-Gima, K., \& Ko, A. (2001). An Empirical Investigation into the effect of Market Orientation on New Product Performance: A Contingency Approach. Journal of Product Innovation Management, 12(4), 275-293.

Boulding, W., \& Christen, M. (2001). First Mover Disadvantage. Harvard Business Review, October, 20-31.

Burgelman, R. (1991). Inter-Organization Ecology of Strategy Making and Organizational Adaptation: Theory and Field Research. Organization Science, 2(3), 239-262. http://dx.doi.org/10.1287/orsc.2.3.239

Christensen, C. M., \& Raynor, M. E. (2003). The innovator's solution: creating and sustaining successful growth. Boston, MA: Harvard Business School Press.

Clarke, N. (2004). HRD and the challenges of assessing learning in the workplace. International of Training and Development, 8(2), 140-56. http://dx.doi.org/10.1111/j.1468-2419.2004.00203.x 
De Geus, A. (2002). Beware: innovation kills. In Hesselbein, F., Goldsmith, M., \& Somerville, I. (Eds.), Leading for Innovation and Organizing for Results (pp. 225-37). San Francisco, CA: Jossey-Bass.

De-wit, B., \& Meyers, R. (2004). Strategy Process, Content and Context (3rd ed.). London: Thomson Learning.

Dougherty, D. (2007). Trapped in the 20th Century? Why model of organizational learning, knowledge and capabilities do not fit, and what to do about them. Management Learning, 38(3), 265-270. http://dx.doi.org/10.1177/1350507607079024

George, G. (2005). Slack Resources and the Performance of the Privately Owned Firms. Academy of Management Review, 48(4), 661-676. http://dx.doi.org/10.5465/AMJ.2005.17843944

Gilbert, C. (2003). The lessons of new-market disruption. HBS Working Knowledge, 15, September.

Hickman, C., \& Raia, C. (2002). Incubating innovation: companies must leverage the full spectrum of innovation, from the incremental to the revolutionary. Journal of Business Strategy, 23(3), 14-19. http://dx.doi.org/10.1108/eb040244

Hisrich, R., \& Peters, M. (2010). Entrepreneurship. London: McGraw Hill.

Hult, G. T. M., \& Ketchen, D. J. (2001). Does Market Orientation Matter: A test of relationship between positional advantage and performance. Journal of Product Innovation Management, 14(4), 243-257.

Hyland, P., \& Beckett, R. (2005). Engendering an innovative culture and maintaining operational balance. Journal of Small Business and Enterprise Development, 12(3), 336-352. http://dx.doi.org/10.1108/14626000510612268

Kanter, R. M. (1996). When Thousand Flowers Bloom: Structural, Collective, Social Conditions for Innovation. In P. S. Meyers (Ed.), Knowledge Management and Organizational design. Boston: Butterworth-Heinemann. http://dx.doi.org/10.1016/B978-0-7506-9749-1.50010-7

Kim, C. W., \& Mauborgne, R. (1999). Strategy, Value Innovation and the Knowledge economy. California Management Review, Spring, 41-54.

Kim, W. C., \& Mauborgne, R. (2005). Blue Ocean Strategy: How to Create Uncontested Market Space and Make Competition Irrelevant. Harvard Business Press.

Lavie, D. (2006). The Competitive Advantage of Interconnected Firm: An Extension of the Resource Based View. Academy of Management Review, 3(3), 638-658. http://dx.doi.org/10.5465/AMR.2006.21318922

Liberman, M., \& Asaba, S. (2006). Why Do Firms Imitate Each Other? Academy of Management Journal, 31(2), 366-85. 
Liedtka, J. M., \& Rosenblum, J. W. (1996). Shaping Conversations: Making Strategy, Managing Change. California Management Review, 39(1), 141-157. http://dx.doi.org/10.2307/41165880

Nonka, I., and Takeuchi, H. (1995). The knowledge Creating Company: How Japanese Companies Create the Dynamics of Innovation. Oxford: Oxford University Press.

Pallant, J. (2005). SPSS Survival Manual (3rd ed.). USA: Open University Press.

Porter, M. (1985). Competitive Advantage: Creating and Sustaining Superior Performance.

Prahalad, C., \& Hamel, C. (1990). The Core Competency of Corporation. Harvard Business Review, 68(3), 79-91.

Quinn, J., \& Voyer, J. (1998). Logical Incrementalism: Managing Strategy Formation. In Mintzberg et al. (Eds.), The Strategy Process, Context, Content, and Cases. London: Prentice- Hall.

Saunders, N. K. (2012). Doing Research in Business and Management: an essential guide to planning your project. London: Financial times Press.

Stalk, G., Evans, P., \& Schulman, L. E. (1992). Competing on Capabilities: The New Rules of Corporate Strategy. Harvard Business Review, March-April, 57-69.

Subramaniam, M., \& Youndt, M. (2005). The Influence of Intellectual Capital on the Type of Innovative capabilities. Academy of Management Journal, 48(3), 450-63. http://dx.doi.org/10.5465/AMJ.2005.17407911

Tabachnick, B. G., \& Fidell, L. S. (2007). Using multivariate statistics. Sydney, Australia: Allyn \& Bacon.

Tellis, G. J. (2006). Disruptive Technology or Visionary Leadership. Journal of Product Innovation Management, 23(1), 34-38. http://dx.doi.org/10.1111/j.1540-5885.2005.00179.x

Tushman, M., Anderson, P., \& O’ Reilly, C. (1997). Technology Cycles, Innovation Streams and Ambidextrous Organizations: Organization Renewal through Innovation Streams and Strategic Change. In M. Tushman \& P. Andersen (Eds.), Managing Strategic Innovation and Change: A Collection of Readings (pp. 3-23). New York: Oxford University Press.

\section{Copyright Disclaimer}

Copyright reserved by the author(s).

This article is an open-access article distributed under the terms and conditions of the Creative Commons Attribution license (http://creativecommons.org/licenses/by/3.0/). 